\title{
KOMUNITAS PELAJAR UTAN KAYU SELATAN
}

\author{
James Digjaya ${ }^{1)}$, Tony Winata ${ }^{2)}$ \\ 1)Program Studi S1 Arsitektur, Fakultas Teknik, Universitas Tarumanagara, digjaya899@gmail.com \\ 2) Program Studi S1 Arsitektur, Fakultas Teknik, Universitas Tarumanagara, tonywinata@ft.untar.ac.id
}

Masuk: 13-07-2020, revisi: 28-07-2020, diterima untuk diterbitkan: 05-09-2020

\begin{abstract}
Abstrak
Tulisan ini merupakan hasil penelitian yang bertujuan untuk merancang sebuah wadah yang dapat mengurangi kesenjangan sosial, mendorong kemajuan hidup masyarakat, mendukung interaksi dari berbagai golongan, serta menyediakan wadah bagi para penerus bangsa yaitu para pelajar. Berlokasi di Jl. Galur Sari Timur no. 8, Utan Kayu Selatan, yang terletak di Jakarta Timur, sebagai kota dengan kesenjangan sosial tertinggi di Provinsi DKI Jakarta, serta kawasan dengan lembaga pendidikan terbanyak pada daerah tersebut. Hasil penelitian menyimpulkan bahwa fungsi tempat ketiga yang diusulkan untuk wilayah ini adalah Perkumpulan Pelajar Utan Kayu Selatan, di mana terciptanya titik temu pelajar sekitar untuk berinteraksi dan bertukar ide, serta mendorong kehidupan masyarakat sekitar untuk menjadi lebih berwawasan luas dan modern untuk mengurangi kesenjangan sosial. Dalam proses perancangannya dipertimbangkan sejarah kawasan, yaitu area hutan dari zaman kerajaan Mataram, kondisi massa sekitar, fungsi dan sifat dari pendidikan, serta sifat third place sebagai sarana interaksi dan refleksi.
\end{abstract}

Kata Kunci: Jakarta Timur; Kesenjangan Sosial; Pelajar; Perkumpulan Pelajar Utan Kayu Selatan

\begin{abstract}
This study aims to find a third place for reducing social disparity, encouraging social growth, supporting social interaction between different social echelons, and providing a decent place for future educated generations. Located in Jl. Galur Sari Timur no. 8, Utan Kayu Selatan, which is situated in East Jakarta, the highest social inequality at Jakarta Province and also a district with the highest education institution. The result of this research leads to the right third place for this area, which is a community based learning center, under the name of Southwood Learning Center, which accommodates meeting point for local learners to interact and exchange ideas, encourage social growth in education and modern perceptions in the process of reducing social inequalities. In the designing process, the designer considered area history, which was a forest during the Mataram kingdom period, present local building forms, the function and character of education, and the traits of a third place as a medium for social interactions and reflections.
\end{abstract}

Keywords: East Jakarta; Social Disparity; Learners; Southwood Learning Center

\section{PENDAHULUAN}

\section{Latar Belakang}

Dewasa ini, sering terjadinya pemaksaan penggunaan suatu tempat, di mana setiap tempat yang memiliki sebuah meja-kursi, wifi dan buka 24 jam dijadikan sebuah third place dengan fungsi yang tidak sesuai. Misalnya kejadian pada akhir Januari 2020 yang sedang tren adalah "McD tempat Makan, bukan tempat Study". (TribunStyle, 2020). Kejadian ini disebabkan oleh sekelompok mahasiswa yang memarahi satu keluarga karena berisik dan mengganggu mereka belajar. Kasus 
kedua adalah pengalaman pribadi sang perancang, di mana sekelompok mahasiswa datang ke kedai kopi untuk belajar, namun hanya satu atau dua orang yang benar-benar menikmati kopi dan sisanya hanya menumpang wifi 24 jam. Dari kedua contoh kasus tersebut menunjukkan perlunya third place yang berfungsi untuk mewadahi perkumpulan aktivitas pelajar.

Pada sisi yang lain, gaya hidup di era modern ini menyebabkan sifat individualitas yang tinggi, dimana masyarakat hanya "terprogram" untuk melakukan pekerjaan selama mungkin dan beristirahat seminim mungkin. Kehidupan tersebut pun juga mempengaruhi para pelajar, khususnya mahasiswa, di mana tuntutan pendidikan memaksakan penggunaan waktu ekstensif untuk belajar atau mengerjakan tugas sekolah atau kuliah sehingga mengurangi waktu untuk bersosialisasi dan refreshing. Oleh karena itu, dibutuhkannya tempat berinteraksi atau refreshing dalam sebuah area belajar bersama, untuk tetap mempertahankan keperluan bersosialisasi namun tidak memakan waktu belajar.

Selain kasus mengenai krisis kebutuhan third place untuk pelajar dan keperluan interaksi antar pelajar, terdapat juga kasus umum yang harus dijawab oleh sebuah third place, yaitu kesenjangan sosial yang disebabkan oleh kemiskinan. Menurut data bps, persentase kemiskinan di DKI Jakarta masih sebesar 3,42\% atau sejumlah 362.300 jiwa (data terakhir BPS September 2019). Untuk menurunkan kadar kemiskinan, selain menyediakan lapangan pekerjaan adalah dengan menyediakan pendidikan. Menurut William G. Tierney, kurangnya pendidikan menyebabkan ketidakadilan sosial dan juga berkurangnya skilled workforce untuk memenuhi tuntutan jaman, yang berujung pada low-wage jobs dan kemiskinan. (Tierney, 2015: hlm. 4-8).

Berdasarkan tiga paragraf terakhir, maka munculah sebuah ide sebagai berikut. "BAGAIMANA JIKA SEBUAH THIRD PLACE DAPAT MENYEDIAKAN KEBUTUHAN EDUKASI, MEMBERIKAN KEMBALI EDUKASI UNTUK KOMUNITAS, NAMUN TETAP MENDORONG INTERAKSI SOSIAL?". Dari pertanyaan tersebut, perancang mulai memikirkan jenis pendidikan yang mampu mewadahi aktivitas pendidikan dan juga mendidik lingkungan sekitar. Jawaban dari pertanyaan tersebut adalah Community Learning Center yang menyediakan sarana Place-Based Education, di mana para pelajar dapat melakukan aktivitas pendidikan diluar jam belajar formal, mengikuti pendidikan informal dan berinteraksi dengan komunitas.

\section{Rumusan Permasalahan}

a. Dimanakah daerah yang sangat membutuhkan third place sebagai sebuah Community Learning Center?

b. Kegiatan apa sajakah yang dapat diusulkan untuk sebuah third place dengan fungsi Community Learning Center?

c. Kontribusi apa yang dapat diberikan third place bagi daerah tersebut?

\section{Tujuan}

Tujuan dari perancangan ini adalah sebagai berikut:

a. Mengusulkan daerah yang sesuai dengan pemahaman masalah dari third place.

b. Menemukan dan menciptakan third place yang sesuai dengan daerah terpilih.

c. Mengubah sebuah daerah menjadi lebih interaktif dan mengurangi individualitas melalui eksistensi third place yang dirancang. 


\section{KAJIAN LITERATUR}

\section{Community Learning Center sebagai sebuah Third Place}

Pada sub-bab ini, perancang akan memaparkan bahwa sebuah community learning center dapat dinyatakan sebagai third place.

\section{Pengertian Pendidikan}

Dalam buku How People Learn, penulis menyatakan beberapa butir mengenai pendidikan dan ilmu yang seharusnya didapatkan setiap orang. Pertama; ilmu dasar setiap orang atau prior knowledge yang mempengaruhi perilaku dan pola kognitif setiap orang didapatkan melalui pengalamannya dengan dunia sosial (interaksi sosial, pengalaman visual dari lingkungan, trauma yang didapatkannya, dan sebagainya). Selain itu, pendidikan paling mudah didapatkan dari interaksi sosial karena memiliki tiga elemen penting, yaitu conserving (bicara), observing (melihat), dan eavesdropping (menguping atau mendengar). Jadi, ilmu pengetahuan pada dasarnya lebih mudah didapatkan melalui berinteraksi dalam sebuah komunitas (keluarga, sanak-saudara, tetangga, dan sebagainya). Kedua, ilmu yang terpenting dalam kehidupan bukan didapatkan melalui pendidikan formal saja. Pendidikan formal hanya mampu menciptakan pola piker abstract theory, namun tidak mampu menyesuaikan individu dengan realita (contextual theory). Contextual theory mampu dipelajari dan dipahami dengan interaksi sosial dalam sebuah komunitas. Ketiga, terdapat empat macam lingkungan dalam meraih ilmu, yaitu learner centered (pola pikir pelajar, minat dan bakat, dan sebagainya), knowledge centered (ilmu melalui pendidikan formal), assessment centered (tugas pribadi dari institusi pendidikan untuk memberikan murid pengalaman trial and error), dan paling terakhir community centered (interaksi sosial, memahami keperluan komunitas, saling memberi kritik dan saran).

Namun, community centered sering dihiraukan oleh karena tuntutan pendidikan modern. Realita tersebut menurunkan kinerja kognitif pelajar maupun pengajar. Community centered merupakan isu penting dalam pendidikan, karena pada dasarnya manusia adalah makhluk sosial. Selain itu, melalui interaksi komunitas, pelajar mendapatkan keahlian diluar pendidikan formal, yang merupakan kunci penting dalam academic achievement, professional skills, dan teamwork yang akan berguna untuk kemudian hari. Dari sisi pengajar, interaksi sosial (informal) juga merupakan factor penting dalam mengembangkan ilmu mengajar, ilmu pengetahuan, kolaborasi, dan pengembangan diri. (National Research Council, 2000).

Maka, dapat disimpulkan bahwa interaksi sosial dalam sebuah komunitas merupakan penting dalam pendidikan dan perkembangan pelajar maupun pengajar. Interaksi sosial juga mampu membantu mempersiapkan pelajar dalam dunia profesional karena memberikan ilmu konteks.

\section{Definisi Community Learning Center dan kaitannya dengan Third Place}

"Life is a continuous learning process", "lifelong learning", atau "continuing education" merupakan dasar atas keberadaannya sebuah community learning center. (UNESCO, 1999: hlm. 2-8). Pada dasarnya community learning center adalah sebuah institusi pendidikan lokal, di luar pendidikan formal (second place), untuk pedesaan maupun perkotaan, yang dikelola dan dikembangkan oleh komunitas sekitar (daerah netral), yang menyediakan berbagai macam pendidikan dan kesempatan untuk meningkatkan kualitas hidup masyarakat sekitar (empowering, equal gender rights, promoting community development). (UNESCO, 1999: hlm. 2-8).

Community Learning Center memiliki ciri-ciri berupa mengembangkan pendidikan informal dan potensi komunitas, mewakili aspirasi dan kebutuhan komunitas, datang dari dan untuk mewadahi 
kegiatan komunitas, dan juga memberdayakan anak-anak, remaja, pekerja, pria maupun wanita, dan sebagainya. (UNESCO, 1999: hlm. 2-8). Ciri-ciri tersebut, terutama mengenai mengembangkan potensi komunitas dan menjunjung tinggi netralisme memperjelas bahwa community learning center merupakan sebuah third place.

\section{Pentingnya Keberadaan Community Learning Center}

Fungsi utama dari community learning center adalah memberikan minat baca dan menulis bagi masyarakat yang kurang berpendidikan, memberikan pendidikan sepanjang eksistensi community learning center untuk meningkatkan kualitas hidup masyarakat sekitar, menanamkan keahlian yang lebih dari pendidikan formal (berupa pendidikan informal) yang dapat digunakan dalam dunia profesional nantinya, menciptakan beragam perkembangan komunitas lainnya dalam waktu singkat maupun jangka panjang. (Azis dan Raza, 2001: hlm. 7-18).

Dari fungsi-fungsi yang disebutkan sebelumnya, dapat dikatakan bahwa community learning center diperlukan oleh karena kegunaannya dalam meningkatkan kualitas hidup masyarakat sekitar, mampu mengumpulkan kaum pelajar dan menginspirasi masyarakat sekitar untuk menjadi terpelajar juga, memiliki fungsi fleksibel dalam mewadahi segala macam kegiatan pendidikan dan kreatif, meningkatkan kesadaran akan komunitas, dan mendorong adanya interaksi yang berkualitas (dengan adanya masyarakat terpelajar, akan munculnya identitas daerah yaitu daerah pelajar dan terpelajar). Selain itu, dari kasus "McD Tempat Makan, Bukan Tempat Study" dan kasus-kasus umum yang terjadi di coffee shop (sekelompok pelajar datang, beberapa beli kopi, sisanya "numpang wifi dan nugas"), menunjukan ketidak tersediaannya fasilitas yang cukup luas bagi para pelajar untuk mengerjakan tugas, berinteraksi bersama, dan juga rekreasi. Sehingga diperlukan community learning center yang memang ditujukan untuk tempat berkumpulnya para pelajar-pelajar penerus bangsa.

\section{METODE}

\section{Pemilihan Tapak}

Tapak dipilih di daerah dengan ketimpangan sosial tertinggi se-DKI Jakarta, namun juga memiliki banyak lembaga pendidikan, agar terciptanya interaksi antara pelajar dan masyarakat sehingga mendorong kemajuan dan kualitas hidup masyarakat sekitar.

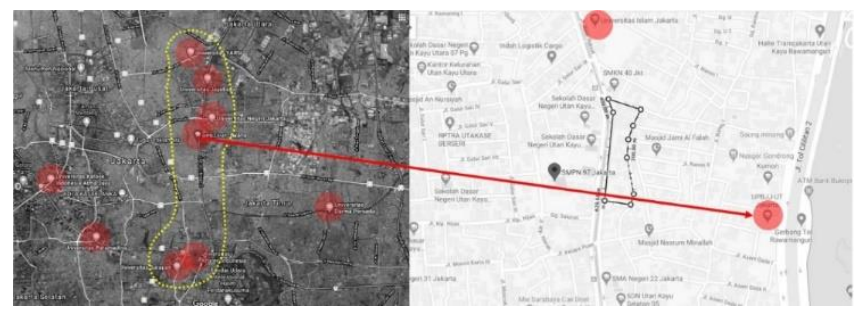

Gambar 1. Peta Kawasan

Berdasarkan data BPS, wilayah DKI Jakarta dengan ketimpangan sosial tertinggi berada pada Jakarta Timur. Area Jakarta Timur dengan perguruan tinggi terbanyak berada pada sepanjang Jl. Ahmad Yani. Dari sejumlah perguruan tinggi tersebut, dipilihkan titik tengah/temu (rendezvous point) di sekitar UPBJJ-UT (Universitas Terbuka). Sekitar daerah tersebut ditemukan area tapak di antara dua perguruan tinggi (UPBJJ-UT dan Universitas Islam Jakarta), serta beberapa sekolah-sekolah lainnya. Tapak tersebut beralamat Jl. Galur Sari Timur no. 8, Utan Kayu Selatan, Jakarta Timur. 


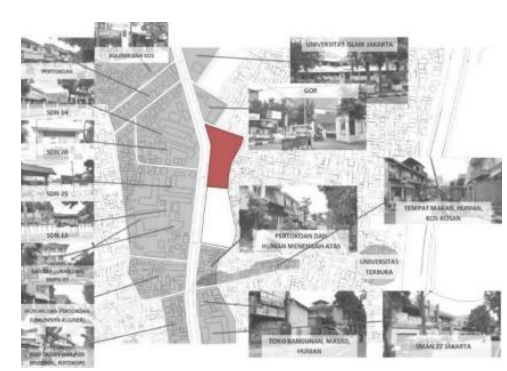

Gambar 2. Lokasi Tapak

\section{Pendekatan Fungsi}

Fungsi third place yang terpilih akan diangkat dari tiga isu yang dibahas dalam latar belakang, yaitu third place untuk pelajar melakukan kegiatan pendidikan, berinteraksi sosial atau refreshing, dan saling mendidik lingkungan sekitar untuk mengurangi kemiskinan dan menyetarakan kesenjangan sosial. Dari paragraf sebelumnya, maka fungsi yang akan disediakan dalam proyek third place ini adalah area luas untuk mengerjakan tugas (atau instalasi maupun prakarya lainnya, dalam bentuk ruang belajar dan outdoor workshop/workspace), perpustakaan dan komputer untuk membantu akses data dalam mengerjakan tugas, ruang rekreasi/playroom dan kafetaria untuk refreshing atau interaksi para pelajar, ruang kelas indoor (pemisah partisi rolling) dan outdoor (outdoor workshop) yang dapat digunakan lingkungan sekitar untuk aktivitas pengajaran pendidikan formal maupun informal, kantor pengurus yang berisi kepala pengurus (pengelola third place), administrasi (mengurus barang masuk dan keluar, serta keperluan lainnya), dan keuangan (mengurus masalah keuangan third place dan donasi). (Aziz dan Raza, 2001: 7-18).

\section{Pengolahan Desain Bentuk Massa}

Terdapat tiga faktor yang digunakan dalam mempertimbangkan bentuk massa. Pertama adalah faktor sejarah, yaitu daerah Utan Kayu Selatan merupakan area hutan yang menjadi sumber kayu kerajaan mataram saat melawan VOC. (Machmud, 2012). Pada zaman kerajaan tersebut, ruang publik merupakan candi yang denahnya dirancang dengan 4 sisi area masuk. (Rahadian, 2007: 74). Untuk menghormati konteks tersebut, ruang tengah yang bersifat sebagai titik temu, yaitu amphitheater, diolah dengan 4 sisi entrance. Kedua, pertimbangan merancang bentuk melingkar, sebagai simbolisasi sirkulasi yang melingkar, sehingga pengguna akan terus bertemu dan berinteraksi. Bentuk melingkar juga merupakan pendekatan kontras terhadap massa bangunan sekitar, sehingga terciptanya identitas bagi sebuah third place pada kawasan tersebut. Ketiga, faktor yang dipertimbangkan juga bentuk massa yang mengikuti garis tapak. Hal ini sebagai pendekatan konteks terhadap garis-garis tapak serta simbolisasi sebuah third place yang mengikuti kegiatan dan mewadahi interaksi manusia.

\section{Pengelolaan Ruang}

Ruangan pada third place ini dikelola sesuai metode pembelajaran baru, yang dinamakan Balanced Curriculum Model. (Koot, 2017). 


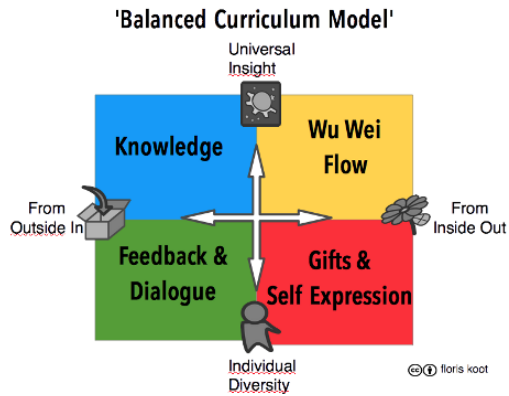

Gambar 3. Balanced Curriculum Model (Koot 2017)

\section{Material Proyek}

Dalam mempertimbangkan material, perancang mengutamakan material berbau hutan atau natural, seperti kayu (serbuk kayu bekas di laminate, papan kayu bekas, bambu) dan material unfinished lainnya, sebagai pendekatan konteks hutan dari daerah Utan Kayu Selatan (dahulunya hutan pada jaman kerajaan Mataram). Selain itu, perancang juga menggunakan kombinasi material transparan dan reflektif sebagai wujud simbolisasi transparansi atau kenetralan pendidikan dan third place sebagai wadah interaksi dan refleksi.

\section{DISKUSI DAN HASIL}

\section{Proses Massa}

Pertama, garis jalanan diteruskan sebagai pendekatan konteks terhadap akses-akses sekitar tapak. Fasad yang terkena panah akan diberikan material transparan.

Ketiga, amphitheatre berpola melingkar dengan 4 sisi entrance diletakan pada tengah tapak. Peletakan dan pola amphitheatre terinspirasi dari ruang publik jaman kerajaan Mataram, yaitu berbentuk candi. (Rahadian, 2007: hlm. 74).

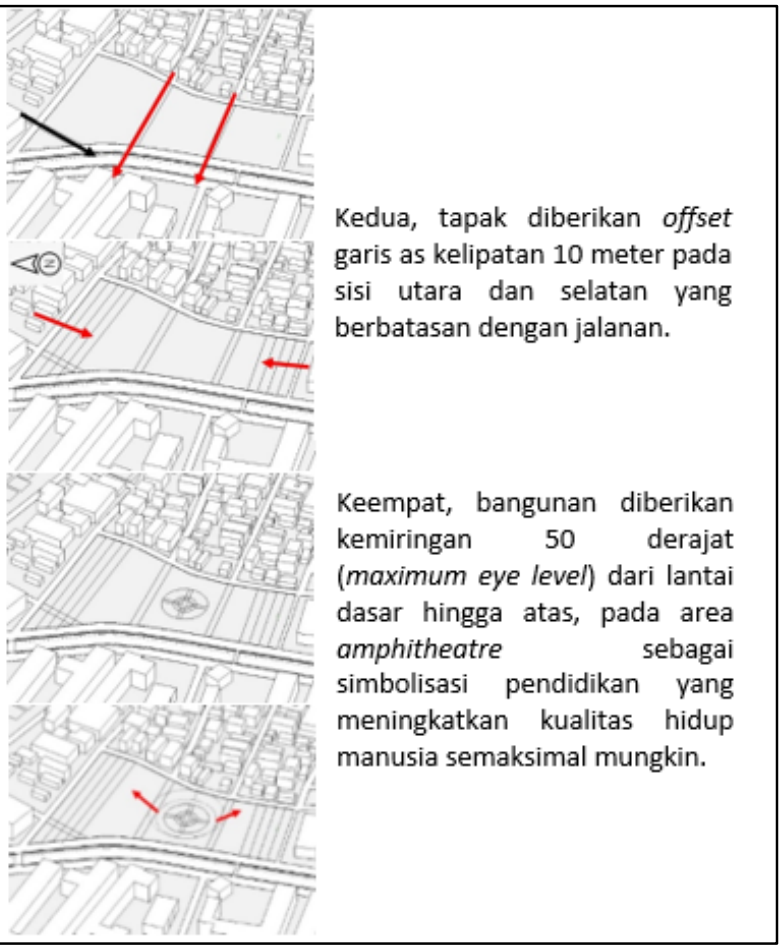




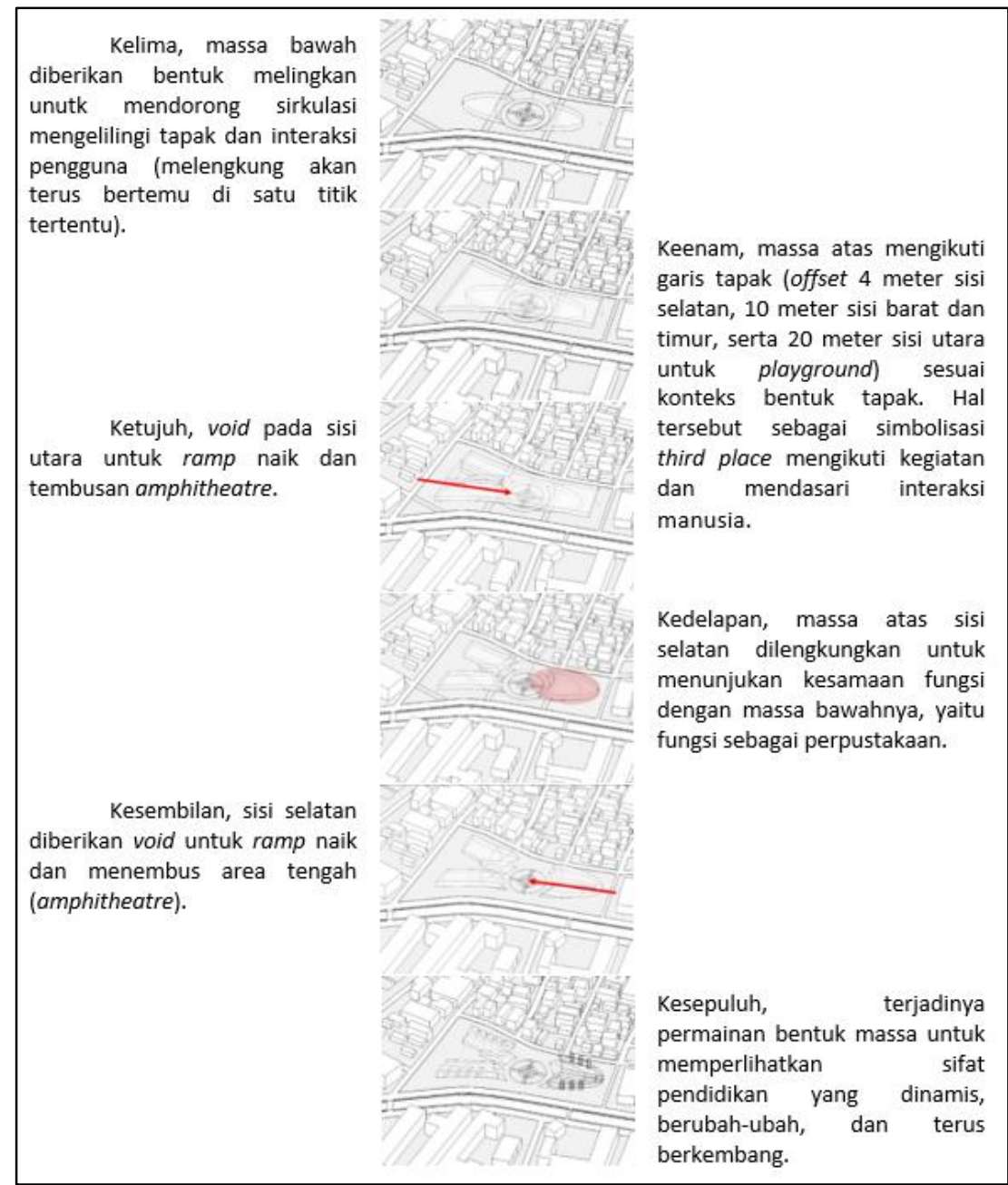

Gambar 4. Proses Massa

\section{Pengolahan Ruang}

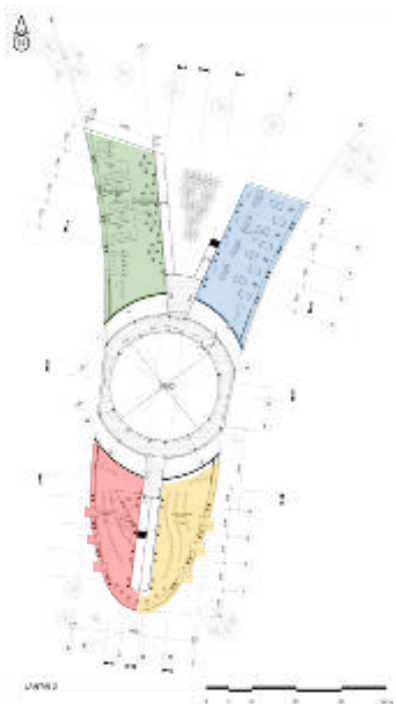

Gambar 5. Denah Lantai 2 
Mengacu pada Gambar 3, ruang belajar bersama, yang terletak di lantai dua, dikelola untuk mengoptimalkan belajar kelompok dan interaksi agar terciptanya feedback and dialogue. Ruang perpustakaan remaja, yang terletak di lantai dasar dan lantai dua, menggunakan rak buku berundak seperti tangga, dengan bentuk yang beragam serta keluar konteks bentuk ruang, untuk melambangkan gifts and self expression masing-masing individu. Ruang perpustakaan dewasa (lantai dua) serta ruang perpustakaan anak (lantai dasar) dikelola dengan konsep wu wei flow (mengikuti arus kehidupan), yaitu perancangan rak-rak buku yang melingkar atau melengkung, sehingga terciptanya sirkulasi layaknya sebuah ombak.

\section{Desain Fasad}

Lantai dasar menggunakan modular berkombinasi dari potongan kayu bekas, kaca, dan void atau lubang untuk pengudaraan alami. Dalam ruangan juga diberikan kipas plafond dan jendela hidup untuk cross ventilation dan tidak memerlukan air conditioning. Pada lantai dasar juga terdapat second skin yang terinspirasi dari balanced curriculum model (sesuai penjelasan konsep fasad). Material yang digunakan adalah besi bekas (container) yang dibentuk dan dipoles ulang, kemudian diberikan rangka besi hollow bekas.

Bangunan ini menggunakan kolom berbentuk $Y$, sebagai simbolisasi batang pohon. Kolom tersebut menggunakan material beton unfinished untuk memperkuat konteks natural dan hutan dari daerah.

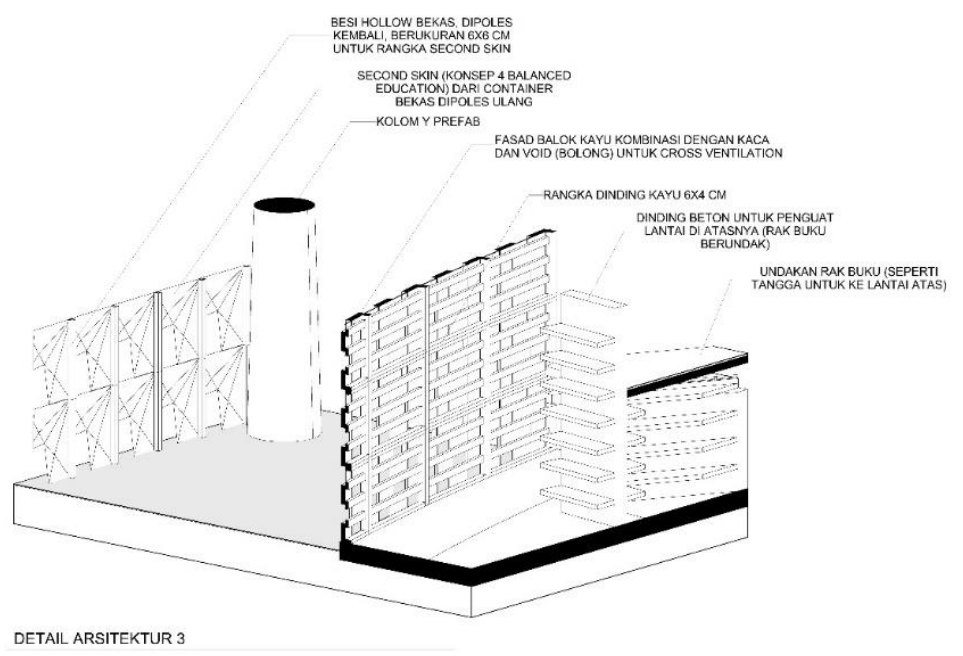

Gambar 6. Detail Dinding Lt. Dasar dan Kolom

Pada area outdoor, terdapat outdoor workshop yang dirancang menggunakan rak modular bermaterial bambu. Rak tersebut juga dapat digunakan sebagai rak tanaman pot. Penggunaan material ini bertujuan untuk memperkuat sifat natural dan hutan pada proyek ini 


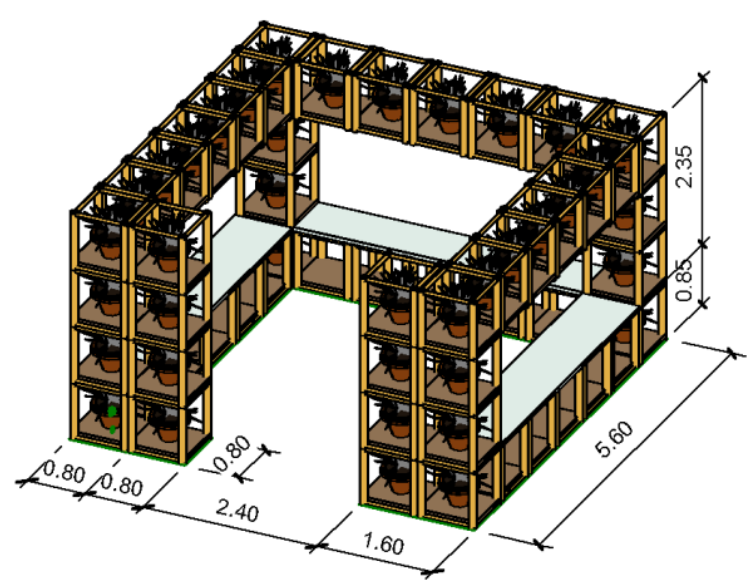

Gambar 7. Detail Outdoor Workshop

Material fasad pada lantai atas menggunakan kombinasi sisa-sisa serbuk kayu yang dilaminate (ketebalan $2 \mathrm{~cm}$ ) dengan sela $4 \mathrm{~cm}$ antara tiap papan (untuk cross ventilation dan simbolisasi sifat transparansi pendidikan), kemudian pada ruangan dalam diberikan kipas plafond dan jendela menghadap taman atau ramp, agar terciptanya cross ventilation dan tidak diperlukannya air conditioning. Rangka dibalik kayu laminasi tersebut adalah bambu berdiameter $10 \mathrm{~cm}$, yang disambungkan dengan papan laminasi menggunakan paku.

Kemudian untuk pencahayaan alami, setengah dari atap tiap sisi massa atas merupakan atap kaca, dengan papan kayu berkemiringan 30 derajat untuk tetap memberikan shading teduh pada penggunanya. Selain itu, atap transit yang dapat digunakan bagi pengguna numpang lewat, merupakan sebuah roof garden dengan alas beton unfinished, untuk memperkuat konteks natural dan hutan. Fasad atas juga menggunakan kaca reflektif untuk memperkuat konteks third place, yaitu sebuah tempat untuk berinteraksi dan berefleksi.

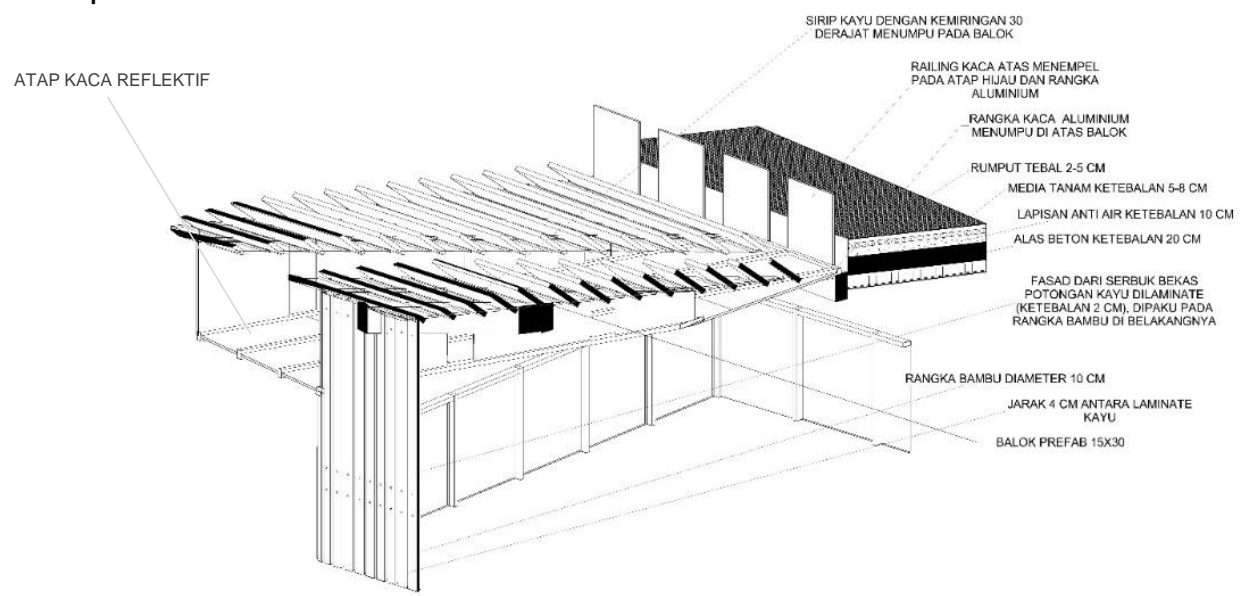

Gambar 8. Detail Atap dan Fasad

Fasad atas (pada area reading cabin) juga menggunakan kaca transparan untuk memperlihatkan transparansi ilmu dan juga memasukan cahaya alami ke dalam bangunan. 


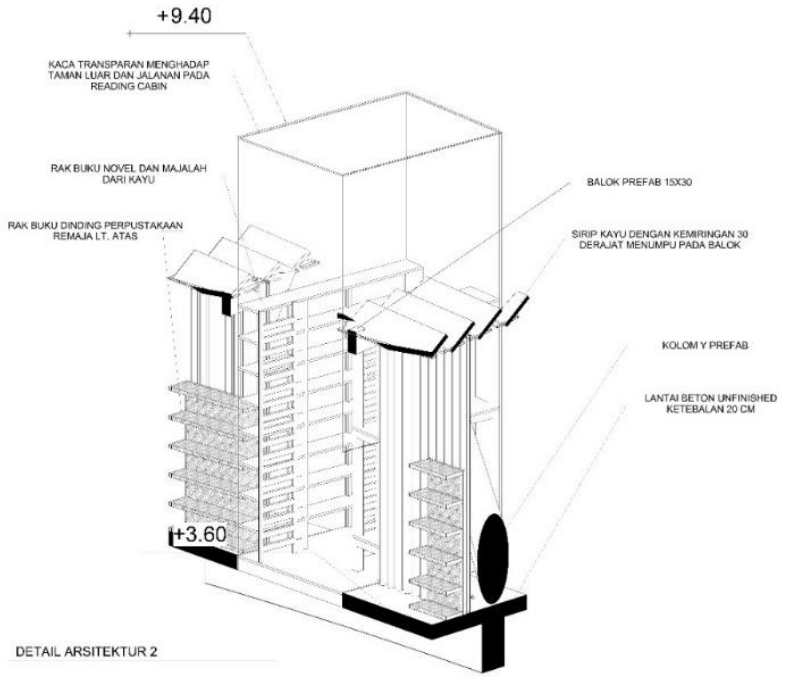

Gambar 9. Detail Reading Cabin

\section{Fungsi Proyek}

Pada proyek ini, fungsi utama yang ditawarkan adalah perpustakaan anak, amphitheatre, perpustakaan remaja, perpustakaan dewasa, ruang belajar dan mengerjakan tugas, dan ruang rekreasi. Fungsi penunjangnya antara lain kafetaria, kiosk disewakan (untuk keberlangsungan proyek ini), kantor pengurus, toilet dan musholla. Fungsi pelengkap lainnya adalah outdoor playground, outdoor workshop, serta parkir kendaraan.

Dalam pertimbangan pengguna dengan beragam golongan umur, fungsi perpustakaan anak dan playground dirancang untuk pengguna anak kecil. Bagi pengguna remaja, terdapatnya perpustakaan remaja, ruang rekreasi (untuk dewasa juga) dan ruang belajar bersama. Bagi para pengguna dewasa, tersedianya perpustakaan dewasa, outdoor workshop, dan kafetaria (untuk segala umur).

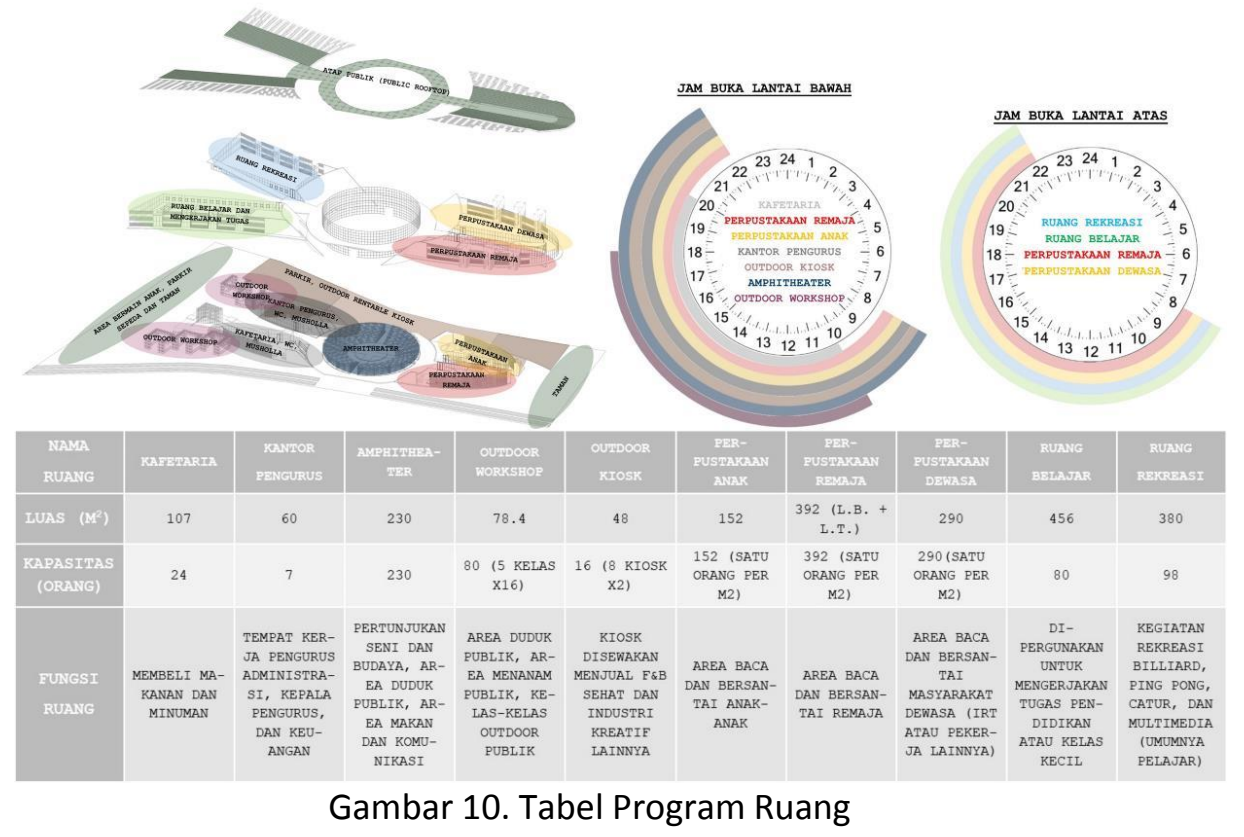




\section{KESIMPULAN DAN SARAN}

\section{Kesimpulan}

Dalam mempertimbangkan fleksibilitas fungsi dan keberlangsungan proyek, perancang menghasilkan ruangan-ruangan sebagai berikut. Ruang belajar bersama pada lantai dua, memiliki ruang belajar kelompok dengan bilik2 partisi sliding, sehingga ruang belajar kelompok tersebut dapat dibesar-kecilkan sesuai kebutuhan kapasitas. Kiosk luar disewakan dan kafetaria berada untuk keberlangsungan tapak (keberlanjutan ekonomi). Ruang amphitheater maupun outdoor workshop yang dapat digunakan untuk duduk dan berinteraksi bebas disaat tidak dipergunakan untuk kelaskelas atau pertunjukan.

\section{Saran}

Saran perancang bagi pembaca adalah dalam merancang sebuah third place, sebaiknya berfungsi sebagai wadah untuk perkumpulan dan interaksi masyarakat sekitar, serta yang mampu mengubah pola hidup penggunanya menjadi lebih baik. Bagi yang ingin merancang community learning center seperti proyek ini, sebaiknya dipilih pada area dengan jumlah area pendidikan yang tinggi dan terletak juga di lokasi dengan kesenjangan sosial tinggi, sebab proyek ini akan mampu membawa dampak baik bagi area tersebut.

\section{REFERENSI}

Akcan, E. (2018). Open Architecture: Migration, Citizenship, and the Urban Renewal of BerlinKreuzberg. New York: Birkhauser.

Koot, F. (2017). Three New Models to Boost Education. Retrieved July 5, 2017, from Medium: https://medium.com/the-gentle-revolution/three-new-models-to-boost-educationbc3a1437d3b2

Machmud, Z. H. (2012). 212 Asal-Usul Djakarta Tempo Doeloe. Jakarta: Ufuk Press.

National Research Council. (2000). How People Learn: Brain, Mind, Experience, and School: Expanded Edition. Washington D.C.: National Academy Press.

Rahadian. (2007). Kajian Aplikasi Gaya Arsitektur Candi Peninggalan Mataram Kuno di Jawa. Bandung: Universitas Katolik Parahyangan.

Sofia Aziz, Syed Farrukh Raza. (2001). Guide Manual for Community Learning Centers. Islamabad: UNESCO.

Tierney, W. G. (2015). Rethinking Education and Poverty. Baltimore: Johns Hopkins University Press. Trancik, R. (1986). Finding Lost Space: Theories of Urban Design. Toronto: John Wiley \& Sons Inc.

TribunStyle. (2020). Retrieved January 30, 2020, from https://style.tribunnews.com/2020/01/30/viral-mcd-tempat-makan-bukan-tempat-studypelajar-tegur-pengunjung-ribut-malah-malu-sendiri?page $=2$

UNESCO, A.-P. C. (1999). Role of Community Learning Center for the Promotion of Literacy and Quality of Life April 1999. Nepal: UNESCO. 
